\title{
New Perspective on Bank Corporate Governance
}

\author{
Yuniarti \\ Faculty of Law, Airlangga University \\ Surabaya, Indonesia \\ yuniarti@fh.unair.ac.id
}

\begin{abstract}
After the 2007 financial crisis, a new perspective on bank corporate governance has been proposed. Explain by discussing the similarities and differences between it and the perspective on bank corporate governance that prevailed before the 2007 financial crisis. As one example, discuss the Basel Principles for Enhancing Corporate Governance (October 2010) in the areas of the "board and senior management" and "executive compensation". Also, discuss some of the main difficulties in implementing the new perspective on bank corporate governance in the above-mentioned areas and identify alternatives to overcome these difficulties
\end{abstract}

Keywords-Bank; corporate governance; new perspective; basel.

\section{INTRODUCTION}

The financial crisis due to the implosion of markets for securitized mortgages in 2007 had awakened new perspective on supervision of bank corporate governance. It is intense to prevent another financial crisis globally. In addition, banking sector has become a highly regulated area because of its unique characteristic which results to state macroeconomic collapse. Nonetheless, the systemic damage of a regulatory failure could be avoidance by having bank corporate governance. The new regime of bank corporate governance evolved to be more risk management, monitoring process and compensation scheme. The principle based regulation make regulation to be more flexible. It is as a result of the evolution of banking structure activities which has become far more complex. However, there
Is difficulties in implementing the new perspective in bank corporate governance.

\section{THE CONCEPT OF CORPORATE GOVERNANCE}

The concept of corporate governance had been various depend on their legal background, cultural and political context, business forms and share ownership.1 Moreover, the concept will be different in Anglo American system and Franco German System. In Anglo American model, the focus is to maximize the value of corporation for improving shareholders values. It is affected by the agency theory, transaction cost economics, stake holders theory and the stewardship theory. Moreover, this disciplines also gained further development from related sciences, such as economics, law, finance, management, and organizational behavior.2 The Anglo American Model is implemented in the United States, England and some other countries. The OECD Principles of corporate governance 2004 set up the definition of corporate governance by providing the structure of the company include a set of relationship between company's management, its board, its shareholders and stakeholders to attain the objectives and performance of the company. 3 However, the similarities could be found in the desire for transparency, accountability and gaining investor confidence. The Cadbury report 1992 had been the code that inspires corporate governance code of conduct in many countries in the world. This code was established by the financial reporting council, the London Stock Exchange and the accountancy profession by establishing the Committee on the Financial Aspects of corporate governance in May 1992.4 The focus of this report is to have the separation 
of power within the chairman and the chief executives. Thus due to the reason that decision makers have to be accountable for their decision to the shareholders as the owner of the company.

In addition, the collapse o Enron and a number of firms had awakened awareness in the US in 2002 by issuing the Sarbanex Oxley Act and reforming the corporate law. This awareness also had affected Europe and the UK. The government become more involves regulating corporate governance because there is a link between corporate governance and economic growth, further effective corporate governance can promote an effective corporate efficiency. Diane K. Denis and John J. McConnell give definition in corporate governance which is as a set of self-interested controllers of a company mechanism that can maximize the profit of the company

\section{THE CONCEPT OF BANK CORPORATE GOVERNANCE}

A proper functioning performance of banking sector and economy as a whole is material to achieve by having effective corporate governance. The emergence of this point is to gain public trust and confidence in banking system.7 This is because bank has special character which made it differ from general corporations as follows:

a. Bank has an important role in macroeconomic, as it is an intermediary institutions between creditors and depositors.

b. Protections to depositors and public interest an essential element in banking industry because this is a leverage business since the funds that involve from the public is extremely greater that the shareholders funds.

c. Bank has a wide range of stakeholders.

d. Cooperation among banks is essential in performing their business.

A poor corporate governance implementation could lead deduction in maintaining their assets and liquidity, which subsequently trigger a liquidity crisis. The vulnerable character of bank made Bank corporate governance different with general firm corporate governance, which mainly because of the deposit insurance and prudential regulation to supervise banking performance and to retain the stability of the business. Otherwise, the collapse of banking business will have effect in the economics domestically and internationally. Furthermore, there is also a difficulty in implementing traditional concept of corporate governance. If the banking sector simply implement it, the transparency point will be difficult to implement due to the economic effect. Once the illiquidity known by the public, it will lose public trust and it will create greater damage than before the information is given. For this reason special banking corporate governance is needed by the banking sector.

The Cadbury report explains that corporate governance is a system to control and directed the firm9, this statement is also applicable in banking corporate governance. However, the main issue in banking corporate governance goes to the shareholders (equity governance), debt governance and supervisors. If the maintenance of those three aspects were failed, it will lead to financial crises. The trends on banking corporate governance awaken since 1997 financial crisis. Since then the Basel committee on Banking Supervision issue the first guideline "Enchanging Corporate Governance on Banking Organisations" in 1999.11 The latest version of this guideline was in 2010, which stated that from banking perspective corporate governance involve the manner of its boards and management as follows:

a. Set the bank strategy and objectives;

b. Determine the bank's risk tolerance/appetite;

c. Operate the bank's business on a day-today basis; 
d. Protect the interest of depositors, meet shareholders obligations, and take into account the interest of other recognised stakeholders; and

e. Align corporate activities and behavior with the expectations that the bank will operate in a safe and sound manner, with integrity and in compliance with applicable laws and regulations.

To ensure the implementation of those objectives the Basel committee issued the sound of corporate governance principles as an important element of an effective corporate governance process. However, one model does not fit all because there are significant differences in legislative and regulatory framework around the world regarding the function of the board and senior management.

\section{BANK CORPORATE GOVERNANCE BEFORE 2007}

Bank corporate governance before 2007 inspire by the Basel Committee on Banking Supervision guidance in 1999. This guidance was based on the principles of Corporate Governance that were published by The Organisations for Economic Co-operation and Development (OECD).14 The standard of bank corporate governance realized to be arranged differently in each countries, due to this reason the purpose of Basel Guideline is to assist government to set a standard regulation to improve the frameworks for the bank corporate governance. Nonetheless, the application will depend on relevant laws, regulation, codes and supervisory in each jurisdictions. The structure of management group also realized to be differ in each system. In one tier system the board has broader role, meanwhile in two tier system the supervisory function perform separately from the board of directors which called the supervisory board. The principles that set up in Basel Committee on Banking Supervision 'Enchanging Corporate Governance for Banking
Organisations' 2006 adopted in Basel II framework.

Further, bank supervision is essential for bank performance. It is carried out by the board of directors and senior managers. The role of this function is to strengthening the corporate governance of the bank. Subsequently, this is also a tool from corporate governance principles to protect depositors. Pillar 2 in Basel II also deal with the supervisory function within the operational risk.15 The main difference between Basel I and Basel II is that Basel II provides for more flexibility and risk sensitive.

Overall the key point in the committee 2006 principle are as follows:

a. The board has to set up the bank's strategy;

b. Diversification and separation of power in the structure of organization;

c. The compensation have to be relevant with the long term objectives;

d. Transparency and risk management.

\section{THE NEW PERSPECTIVE ON BANK CORPORATE GOVERNANCE}

The Basel Committee on Banking Supervision 'Enchanging Corporate Governance for Banking Organisations' 2010 published as a respond of the Basel principle 2006 failure. The challenge to implement corporate governance is when the bank structure ownership is unduly complex, lack transparency and insufficient balances. It also requires effective legal and institutional foundations. The Basel guidance 2010 is as follows:

a. Principle 1: "The board has ultimate responsibility for the bank, including approving and overseeing the implementation of the bank's strategic objectives, risk strategy, corporate governance and corporate values. The board is 
also responsible for providing oversight of senior management." The bank corporate values and code of conduct become an important element in 2010 guidance and the board has to communicate and ensure it is perform appropriately throughout the company.

b. Principle 2: "Board members should be and remain qualified, including through training, for their positions. They should have a clear understanding of their role in corporate governance and be able to exercise sound and objective judgement about the affairs of the bank." This principle is similar with the previous guidance, the different is that in 2010 guidance allow training as an assistant to the board to maintain and deepen their knowledge.

c. Principle 3: The board plays an important role in the bank, they have to maintain, update organizational rules, by laws and others key activities. They also have to hold a meeting periodically to review critical decisions and issues. Their decisions have to be supervise by the chair and ensured that the decisions an appropriate check and balances. The board committee in every jurisdiction commonly has compensation committee, nomination/human resources/governance committee and ethic/compliance committee. Those special committee were chosen by the board based on the skills and experience. In addition, the board has to maintain external conflict with other banks and make an appropriate public disclosure.

d. Principle 4: "In a group structure, the board of the parent company has the overall responsibility for adequate corporate governance across the governance across the group and ensuring that there are governance policy and mechanisms appropriate to the structure, business and risks of the group and its entities.".

e. Principle 5: "Under the direction of the board, senior management should ensure that the bank's activities are consistent with the business strategy, risk tolerance/appetite and policies approved by the board.". Senior management consists of experience and competence group of people under direction from the board. The task is to ensure the implementation of bank sound corporate governance of the bank in day-to-day practices.

f. Principle 6: Bank has to maintain and design the risk management and set up internal controls, even in a very small bank. The objective of this principle is to have a reasonable check on managerial and employee discretions. Meanwhile in internationally active banking, there should be an independent senior executive to handle a comprehensive risk management system.

g. Principle 7: Researching the risk methodologies and activities both in qualitative and quantitative elements. The principle also promotes the importance of senior management.

h. Principle 8: An effective communication about risk management both horizontally and vertically have to be carried out.

i. Principle 9: An effective work of internal audit function, external auditors and internal control functions by the board and senior management. In addition, compensation systems become key components of bank governance and risk management.

j. Principle 10: the compensation system operation and design is overseen by the board.

k. Principle 11: the compensation scheme has to be adjusting for all types of risk, include the employee's compensation and it also have to be consistent with the right alignment.

1. Principle 12: "The board and senior management should know and understand the bank's operational structure and the risks that it poses (i.e. "know-your-structure).

m. Principle 13: In case that a bank operate in a legal framework that does not meet international banking standards, the board and senior manager have to identified the risks of the system. 
n. Principle 14: An accurate, clear and presented in understandable manner of disclosure and transparency to shareholders, depositors, other relevant stakeholders and market participants."

Basel guidance 2010 set principles of the role of supervisory body that can assist supervisors in assessing corporate governance. The principles are as follows:

a. The supervisors should provide guidance to bank expectations;

b. The Supervisors should regularly perform a comprehensive evaluation;

c. The supervisors provide internal reports and prudential reports;

d. The supervisors should require effective and timely remedial action and have an appropriate tools for this;

e. The supervisors have to cooperate with other relevant supervisors in other jurisdictions.

In general the Basel guidance 2010 focus greatly on risk mitigation and maintenance. It demands to provide overall supervisory activity to be tightly monitor and reporting gradually to shareholders, depositors, stakeholders and other market participants. Moreover, the development of monitoring process also take a significant issue in Basel guidance 2010. Meanwhile, the similarities issues between both guidance are the disclosure, strategy design based on the board of directors and supervisory setting, separation of power and remuneration scheme. Basel guidance 2010 is the underlying guidance to published Basel III, which main objective is to strengthening global capital and liquidity rules with the goals to promote a resilient banking system.16 Nonetheless, difficulties in implementing this guidance are in researching the risk mitigation and maintaining it. This process will acquire a costly process and resources. To overcome this problem a consolidated coordination between the board of directors and supervisory body would be more efficient. However, this practice is an important element to gain public confidence in banking system. A strict regulation in supervision and risk mitigation and maintaining will guarantee an appropriate banking management and bank corporate governance.

\section{CONCLUSION}

Banking corporate governance is a lex specialis of the traditional corporate governance concept, due to special characteristic in banking system, depositors protection and prudential regulation. Moreover, the effect of banking collapse will also affect the macroeconomic activity. The new regime of bank corporate governance evolved to be more risk management, monitoring process and compensation scheme to guarantee depositors protection and ensure liquidity stability. The financial crisis after 2007 has awakened a new perspective in monitoring process, risk management and compensation scheme of all stakeholders. Meanwhile, previous banking corporate governance still concern about the remuneration and separation of power in top management level. The new perspective will cause a costly process, nevertheless it will worthy practice to guarantee the liquidity and gain public confidence in banking sector.

\section{REFERENCES}

[1] Basel Committee on Banking Supervision, 'Enchanging Corporate Governance for Banking Organisations',2006.

[2] Benton E. Gup, 'Corporate Governance in Banking: A Global Perspective',Edward Elgar, 2007.

[3] Christine A. Mallin, 'Corporate Governance',Oxford University Press, 2013 Finance the Regulatory Challenge', John Wiley\&Sons, 2006.

[4] Hamid Yunis, 'Corporate Governance for Banks', in Simon Archer and Rifaat Ahmed Abdel Karim, 'Islamic 
[5] K. Keasey, S. Thompson and M. Wright, corporate governance : accountability, enterprises and international comparisons, John Willey \& Sons, 2005.

[6] Nicholas Dimsdale and Martha

Prevezer, ' Capital Market and Corporate Governance', Oxford University Press , 2001

[7] Thomas Clarke, 'International Corporate Governance: A Comparative Approach', Routledge, 2007.

[8] Adrian Cadbury, 'Report of the committee on the Financial Aspects of Corporate Governance', December 1992, available at $<$ http://www.ecgi.org/codes/documents /cadbury.pdf >

[9] E. Wymeerrsch, K. Hopt, G. Ferrarini, eds, 'Financial Regulation and Supervision: a Post Crisis Analys is' <http://papers.ssrn.com/so13/papers.cf m?abstract_id=1918851 >

[10] KPMG.com, Basel III: Issues and Implications, available at <http://www.kpmg.com/Global/en/Issu esAndInsights/ArticlesPublications/Do cuments/basell-III-issuesimplications.pdf>

[11] OECD Principles of Corporate Governance , revised April 2004, originally issued June 1999. 